\title{
The effects of soaking for DNA recovery on the striation patterns of fired cartridge cases
}

\section{E. Prasad, L. Van der Walt, A. Cole, R.A.H. van Oorschot, M. Barash, P. Gunn \& J. Raymond}

To cite this article: E. Prasad, L. Van der Walt, A. Cole, R.A.H. van Oorschot, M. Barash, P. Gunn \& J. Raymond (2019): The effects of soaking for DNA recovery on the striation patterns of fired cartridge cases, Australian Journal of Forensic Sciences, DOI: 10.1080/00450618.2019.1569144

To link to this article: https://doi.org/10.1080/00450618.2019.1569144

舟 Published online: 24Jan 2019.

Submit your article to this journal $\square$

Џll Article views: 49

View Crossmark data ¿ 


\title{
The effects of soaking for DNA recovery on the striation patterns of fired cartridge cases
}

\author{
E. Prasad ${ }^{a}$, L. Van der Walt ${ }^{b}$, A. Cole ${ }^{b}$, R.A.H. van Oorschot ${ }^{c, d}$, M. Barash ${ }^{a}$, P. Gunn ${ }^{a}$ \\ and J. Raymond
}

${ }^{a}$ Centre for Forensic Science, University of Technology Sydney, Australia; ${ }^{\text {b}}$ Forensic Ballistics Investigation Section, NSW Police Force, Australia; 'Office of the Chief Forensic Scientist, Victoria Police Forensic Services Centre, Australia; ${ }^{d}$ School of Molecular Sciences, La Trobe University, Australia; eForensic Evidence \& Technical Services Command, NSW Police Force, Australia

\begin{abstract}
The recovery of trace DNA from fired cartridge cases has recently gained increased interest throughout the literature, with a variety of methods currently being explored. Soaking fired cartridge cases in a lysis buffer holds potential in producing meaningful DNA profiles; however, chemical interactions between the lysis buffer and brass cartridge cases may limit the efficacy of this method. This preliminary study examines the effects of soaking on the microscopic striation detail of brass and nickel $9 \mathrm{~mm}$ Parabellum (9 $\mathrm{mmP}$ ) calibre and .22 Long Rifle (.22LR) calibre fired cartridge cases. Headstamp and coarse striation patterns on $9 \mathrm{mmP}$ fired cartridge cases and finer striation patterns along the outer wall of .22LR fired cartridge cases were microscopically examined prior to and following soaking. Soaking was performed by submerging the fired cartridge cases in $380 \mu \mathrm{l}$ of ATL buffer (Qiagen, Germany) for 20 minutes. Microscopic analysis of brass and nickel $9 \mathrm{mmP}$ and .22LR fired cartridge cases showed that coarse and fine striation detail remain unaffected following soaking. These results indicate that comparative ballistics examinations may be performed following DNA recovery using the soaking method.
\end{abstract}

\section{ARTICLE HISTORY}

Received 19 December 2018

Accepted 7 January 2019

\section{KEYWORDS}

Cartridge cases; touch DNA; firing effect; striations

\section{Introduction}

Markings imparted on fired cartridge cases that occur in the firearm during loading, discharge and ejection offer forensic firearms examiners valuable information to make identifications or exclusions between fired ammunition components and specific firearms. Comparably, the transfer of trace DNA onto ammunition during the process of loading firearms can offer probative information on the handlers of the ammunition. However, previous attempts to type DNA from fired cartridge cases have resulted in limited success. A novel method published by Dieltjes et al. ${ }^{1}$ involved soaking fired ammunition in a tissue lysis buffer, and it reported success rates of up to $26.5 \%$ in the criminal cases investigated using the technique. Evaluation of the soaking method proposed by Dieltjes et al. ${ }^{1}$ has demonstrated promising results; however, chemical interactions between the brass 
cartridge cases and the lysis buffer may limit this process. ${ }^{2}$ The effects of the buffer chemistry on the microscopic details of fired cartridge cases are also unknown.

The current preliminary study is aimed at observing the effects of the lysis buffer on microscopic striation detail required by ballistics for analysis and is part of a larger project studying trace DNA recovery from fired cartridge cases.

\section{Material and methods}

Brass and nickel CCl .22 Long Rifle (LR) calibre ammunition was used in this study, along with brass Geco $9 \mathrm{~mm}$ Parabellum $(9 \mathrm{mmP}$ ) calibre ammunition and nickel Federal Premium $9 \mathrm{mmP}$ calibre ammunition. Three fired cartridge cases of each calibre and metal composition were analysed.

Prior to soaking, coarse striations patterns on the $9 \mathrm{mmP}$ fired cartridge cases and finer striation patterns on the $.22 \mathrm{LR}$ fired cartridge cases were microscopically analysed under the Projectina AG Vision X comparison microscope by trained ballistics experts. The fired cartridge cases were then submerged in $380 \mu$ of ATL buffer (Qiagen, Germany) at room temperature for 20 minutes, whilst being periodically rotated to ensure optimal coverage. Following 20 minutes of soaking, the fired cartridge cases were removed from the ATL buffer, wiped dry with paper towels, and immediately reanalysed microscopically.

\section{Results}

Submersion of the brass cartridge cases in the ATL buffer resulted in a chemical interaction between the copper from the brass casings and the lysis buffer, evident in a blue colour change. However, a similar reaction was not observed when nickel cartridge cases were submerged in the ATL buffer.

Comparative analysis of coarse striation detail and firing pin impressions on the brass $9 \mathrm{mmP}$ calibre cartridge cases (Figure 1) and finer striation detail on the outer wall of the

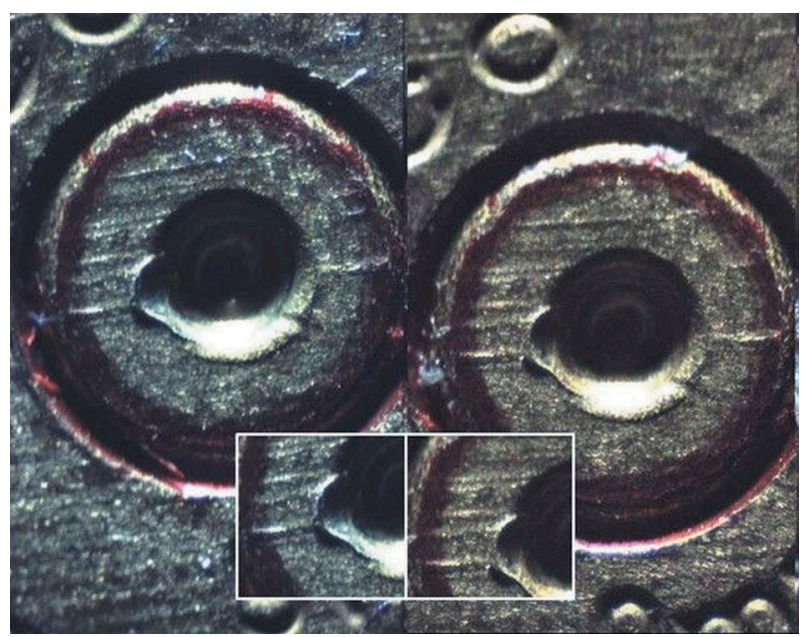

Figure 1. $9 \mathrm{mmP}$ brass fired cartridge case before soaking (left) compared with after soaking (right). 


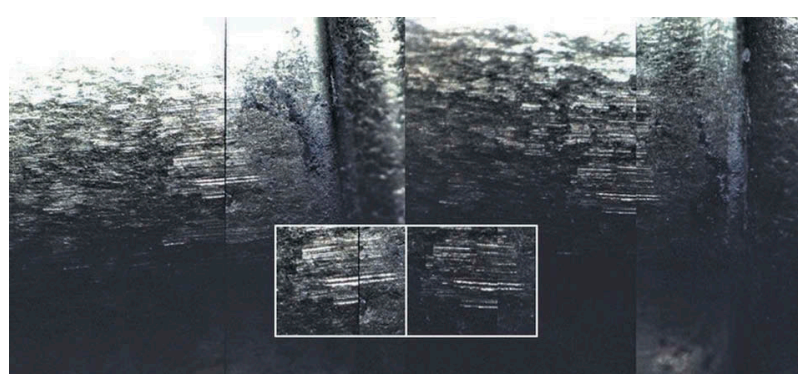

Figure 2. 22LR brass fired cartridge case before soaking (left) compared with after soaking (right).

brass .22LR calibre cartridge cases (Figure 2) showed that the microscopic detail remained unaffected following 20 minutes of soaking and the resulting chemical interaction.

Comparably, pre- and post-analysis of the firing pin impressions and coarse striation detail on the nickel $9 \mathrm{mmP}$ calibre cartridge cases and finer striation detail on the outer wall of the nickel .22LR calibre cartridge case showed no detrimental changes after 20 minutes of soaking.

These results suggest that despite any observable chemical interactions between the lysis buffer and fired cartridge cases, soaking does not influence the quality of the microscopic striation detail required for further forensic analysis.

\section{Conclusion}

From the microscopic comparisons of fired cartridge cases prior to and following soaking, it has been shown that the ATL buffer has no damaging effects on striation details. Therefore, based on the current results, microscopic analysis of fired cartridge cases can be performed subsequent to DNA recovery utilizing the soaking method.

\section{Acknowledgements}

The authors would like to thank the NSW Police Force Forensic Ballistics Investigation Section for their support with the collection and analysis of the fired cartridge cases used in this study.

\section{Disclosure statement}

No potential conflict of interest was reported by the authors.

\section{Funding}

This research project is supported by an Australian Government Research Training Program Scholarship. This project is also funded by the NSW Police Force with additional assistance from the UTS Centre for Forensic Science. 


\section{References}

1. Dieltjes $P$, Mieremet R, Zuniga S, Kraaijenbrink T, Pijpe J, de Knijff P. A sensitive method to extract DNA from biological traces present on ammunition for the purpose of genetic profiling. Int J Legal Med. 2010;125(4):597-602. doi:10.1007/s00414-010-0454-4

2. Prasad E The recovery of DNA from fired cartridge cases [unpublished MSc Thesis]. University of Technology Sydney; 2016. 